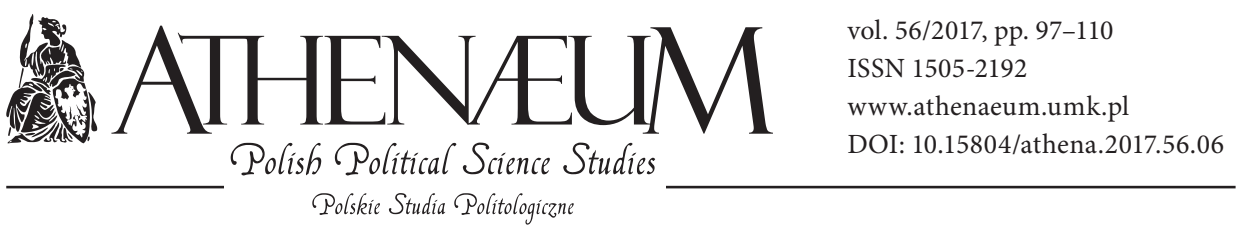

\title{
CONFUCIAN THOUGHT AFFECTING EDUCATION IN SOUTH-EAST ASIAN COUNTRIES VS. SOCRATIC EDUCATION PHILOSOPHY IN WESTERN COUNTRIES*
}

\author{
POGLĄDY KONFUCJUSZA ODDZIAŁUJĄCE NA EDUKACJĘ \\ W KRAJACH POŁUDNIOWO-WSCHODNIEJ AZII A FILOZOFIA \\ EDUKACJI SOKRATESA W KRAJACH ZACHODNICH
}

Stanisław Juszczyk**, Yong Deog Kim***

\begin{abstract}
- ABSTRACT
Socrates and Confucius constitute roots of western and eastern civilization respectively and represent very different cultural values and educational traditions. Both of the philosophers lived around $4-5^{\text {th }}$ century B.C.E., but there were huge differences in the social and cultural environments in which they lived. Different cultural and social factors in ancient Greece and China led to differences in Socratic and Confucian approaches to learning. Their educational philosophies have been discussed on the base of the aim of education, the content of education, the teaching process, and the nature of the contemporary education. The method used in the described study is hermeneutics, or interpretation of the literary (here scientific) texts, thus the study is cross-cultural in nature and concerns the features of the contemporary education in both cultures.
\end{abstract}

Sokrates i Konfucjusz stanowią o fundamentach odpowiednio zachodniej i wschodniej cywilizacji i reprezentują bardzo różne wartości kulturowe oraz tradycje edukacyjne. Obaj filozofowie żyli około IV-V wieku przed naszą erą, lecz w bardzo różnych środowiskach społecznych i kulturowych. Różne czynniki kulturowe i społeczne w starożytnej Grecji i Chinach doprowadziły do różnych poglądów Sokratesa i Konfucjusza na uczenie się. Ich filozofie edukacji zostały poddane dyskusji na bazie celów edukacji, zawartości merytorycznej, procesu nauczania i natury współczesnej edukacji. W opisanych badaniach użyto metodę hermeneutyczną, zwaną inaczej interpretacją tekstów literackich (tutaj naukowych), z tego powodu badania mają charakter interdyscyplinarny i dotyczą cech współczesnej edukacji w obu kulturach.

* This study was supported by Hankuk University of Foreign Studies Research Fund of 2017.

** University of Silesia in Katowice, Faculty of Education and Psychology.

** Hankuk University of Foreign Studies in Seoul, College of Central and East European Studies. 
Keywords: Socrates, Confucius, culture, education, learning, Western countries, Asian countries
Słowa kluczowe: Sokrates, Konfucjusz, kultura, edukacja, uczenie się, kraje zachodnie, kraje azjatyckie

\section{INTRODUCTION}

The major actions in many countries concern an enhancing quality of education. Because of globalization, we can compare the effective of different educational systems in many countries placed in different continents. The OECD publishes comparisons on the effectivity and quality of educational systems in many countries. In 2014, Pearson Education released its annual global educational performance report. Once again their findings provide a roadmap for teaching students in the $21^{\text {st }}$ century and for why Asian nations are racing ahead. Pearson found that when national educational systems placed a priority on basic skill development such as numeracy and literacy, these countries should be on the top of countries overall in the international tests. Not surprisingly, the South East Asian countries such South Korea (No. 1), Japan (No. 2), Singapore (No. 3), and Hong Kong (No. 4) clinched the top four spots in an education index produced by Pearson. These four countries beat 39 countries in the Global Index of Cognitive and Education Attainment compiled by the EIU which measures learning ability as well as literacy and graduation rates.

An accompanying report said that these countries are well characterized by a strong community culture dedicated to education (Morris, 2014). Huib Wursten and Carel Jacobs (2017) stated that the conclusion of "the learning curve" is that two issues, highly influenced by culture, were globally recognized as the core of understanding educational quality:

- Supportive culture for education, and

- The need for a high status of teachers.

All the territories of Vietnam, Shanghai (China), Hong Kong, Singapore, South Korea, Japan, and Malaysia are described as "Confucian Heritage Cultures - CHC", because Confucian societies are characterised by the strong emphasis they place on education. Talking about education Confucius said that: (a) moral training is a key part of education and that such knowledge cannot remain academic, but must be reflected in behaviour: a good teacher must be a good moral exemplar; (b) education should be open to all; (c) education is a serious business (The Analects). 


\section{METHODOLOGY OF THE RESEARCH}

The purpose of the presented research is to look at how culture affects education of students from the chosen East-South Asian countries as well as the European Union countries, here called Western ${ }^{1}$ countries. The proposed main research question was following: How do societal and educational cultures affect the Asian educational experiences of students from $\mathrm{CHC}$ and Western European students? The sub-questions ask: What were the social and cultural contexts that formed Socratic and Confucian philosophy of education? What is the impact of their educational philosophies on Western and Asian education? What is the type of societal culture in $\mathrm{CHC}$ and Western countries? What societal and educational cultures affect learning in $\mathrm{CHC}$ and Western countries? How does culture affect communication in $\mathrm{CHC}$ and Western classroom setting?

In the qualitative paradigm of the empirical research we want to look at a personal interaction between two cultures: a background culture and experienced culture. A qualitative research does just that; researchers attempt "to make sense of, or to interpret, phenomena in terms of the meanings people bring to them" (Juszczyk, 2013). The method employed in the study is hermeneutics, or interpretation of the literary texts, thus the study is also cross-cultural in nature. We have taken into account the chosen published opinions on the influence of culture on society and education, the selected published results of the empirical research conducted by different authors in this subject. Cross-cultural study refers to the process of looking at cultural phenomena from the perspective of both cultures in which they occur (Pusch, 1997).

The culture can by shared not only by a group but also individually experienced (Ark, 2013). The analysis has been done in the framework of the critical theory, which can be defined as a social theory where issues of concern focus on the idea of power and justice and the ways that notions such as race, class, ideologies, education, and cultural dynamics interact and how we can better understand these interactions to create justice for all involved (Kincheloe, McLaren, 2000). The study attempts to provide a better understanding of how the Asian and European students interact with their education and how culture, origin of which are the Confucius and Socrates' philosophy, impacts on education in these countries.

1 In the literature the term "the West" largely refers to Europe and the United States, which found their origin in the ancient Greek and Roman culture, and the term "the East", Northeast Asian countries, especially China, Japan, and Korea, which are under the impact of Sinitic cultures. 


\section{EXPLANATION OF WORKING TERMS}

Before we start our discussion, we should explain a few working terms: philosophy of education, culture, societal culture, educational culture, and culturally relevant pedagogy:

- Philosophy of education is close to epistemology, or theory of knowledge, a component of philosophy, and it concerns with virtually every aspect of the educational enterprise (Chambliss, 1996);

- Culture is empirically a multi-faceted concept and in anthropology, different cultures have developed different concepts of responsibility, self and understanding (Markus, Kitayama, 1991) - a meaning system shared by the majority of people who live or interact in the certain space that helps dictate how people work with one another, how they communicate, how they govern themselves, how they interact with the land, and how they educate. Culture can manifest itself in a variety of ways, explained by many authors (Gudykunst, Matsumoto, 1996; Hall, 1976; Hofstede, 1980, 2001; Ting-Toomey, Chung, 1996). M.D. Pusch (1979) defines culture as "the sum of total ways of living, including values, beliefs, aesthetic standards, linguistic expression, patterns of thinking, behavioural norms, and styles of communication which a group of people has developed to assure its survival in a particular physical and human environment";

- Societal culture - the thoughts and views shared by a group of people that affect communications, interactions, how others are treated, and how one interacts with the world around them (Gudykunst, Ting-Toomey, Nishida, 1996);

- Educational culture - the thoughts and views shared by a group of people about how members of the culture should be educated and what is valued in that education;

- Culturally relevant pedagogy - based on the idea that learning is the process that is mediated by the culture and social structure of the area. This means that no curriculum is natural or culturally unbiased; curriculum relies on culture and political power at the time of its creation (Irvine, 2010; Ladson-Billings, 1995; Moore, 2000). 


\section{THE CONFUCIAN EDUCATION MODEL IN CHC COUNTRIES}

Kong Qiu, generally known in China by the respectful appellation Kongfuzi, "Master Kong", lived from 551-479 B.C.E. Jesuit missionaries Latinised this to Confucius, and that of his famous follower Mengzi to Mencius, the names by which they are generally known in the West. Confucius was the first in an age of Chinese philosophers contemporary with the great philosophers of Ancient Greece, but the main focus of Chinese philosophy was government and ethics rather than logic. He was a great thinker and educator as well as one of the most learned people in China at that time. For Confucius, the primary source is the Analects (1990), which was compiled by disciples within a generation or two after Confucius' death (Chen, 1990; Tweed, Lehman, 2002), but his ideas are still unfamiliar to many in the West. He is praised in China as a great teacher and Confucius' heritage is central to people's fundamental beliefs in education including China, Japan, and Korea. Confucianism, as the Golden Rule or a national cult, affected the state's politics, economic, society, culture, and education during many centuries (Hwang, 1999, 2001).

According to the opinion of Don Starr (2012), this philosophy was based on three Hs: humanism, harmony, and hierarchy. He added that there are three Confucian principles underlying this: education is serious; progress is achieved through hard work; everyone can succeed if they work enough. The last of these marks an important Confucian concept about individual perfectibility. Failure to learn is seen as the result of lack of application rather than lack of ability. Some people are slower than others, and they can be helped by the teacher or fellow students outside the class if necessary, but all can succeed in the end.

Confucianism, which was transmitted to Korea through continental China before the diffusion of Chinese civilization (Yun, 1996), has been the main tendency of traditional thought that deeply spread its roots in Korean society, and the Korean people respected Confucian learning and attached great significance to education (de Bary, 1996; Juszczyk, Kim, 2017).

W.O. Lee (1996) characterizes the conception of education in the Confucian tradition with the help of the following major themes: (a) the significance of education: "The significance of education stands out in the Confucian tradition. Education is perceived as important not only for personal improvement but also for societal development"; (b) continuous development; (c) educability for all and perfect ability for all; (d) learning effort and will power. 
As for teaching method, Confucius adopted the approach of "educating someone according to his natural ability" and "heuristic education" (The Analects). He claimed that he was "a transmitter and not a maker" (The Analects). For him learning was viewed as a process by which individuals' minds acquire what is out there; and education is taken in terms of cultural transmission, service to society, and moral transformation. Therefore its teaching model one can describe as the model of "knowledge-transfer", where knowledge is presumed to transfer from one who has it to one who does not (Wang, 2013). Gary Alan Scott (2000) writes that the "knowledge-transfer" model assumes that learning is defined by an increase in the sum of the factual information at one's disposal; and so, from this point of view, new information is merely added to whatever knowledge one previously had, like new data is added to a data bank or inventory is added to a warehouse.

\section{CONFUCIUS' IDEAS ABOUT EDUCATION - IN PRACTICE}

The specific features of Confucian Heritage Cultures in education are: a process of learning by induction, the generation of concepts and the inference of highlevel principles through repeated observation, practising and memorisation of empirical examples. Learners make meaning by generalising concepts from and in relation to what they already know, or what they have observed. In this "model" of Asian learning an inductive pedagogy is used (Watkins, Biggs, 1996).

Confucian values and norms are mainly centred on examinations. Most Asian students have to memorize their lessons, especially definitions, rules, procedures, facts, concepts, and short reading selections such as poems and very short passages. In some schools, students who failed to memorize their notes are made to stand in class until they can recite whatever was assigned to be memorized. The examination includes fill-in-the-blanks items, definition of terms, and enumeration. Teachers find these test items easy to prepare and to check. If they give test items with multiple choice questions, the choices are not chosen well, leading to too obvious answers or confusing answers (Education style, 2017). Regarding the reflections of Confucianism in contemporary Korean higher education, Confucian leadership is based on two main themes: personal order and socio-political order. As Jeong-Kyu Lee (2001) writes, based on the dual Confucian leadership, the characteristic of leadership in Korean higher education is still hierarchically authoritative in general. In recent years, with the achievement of higher stages of 
economic development in Korea, Confucian values and principles are gradually decreasing, while Western values and assumptions are rapidly increasing.

In Asian schools the relationship between students and teachers is clearly social hierarchical since students should show respect to teachers and avoid disagreeing with them as much as possible. Due to the hierarchical and formal relationship, the thought of talking to teachers about matters outside school makes Asian students cringe. The courses in most Asian education systems are heavily lecture-based, meaning that teachers unilaterally transfer information to students. When the teacher is talking, students are taking meticulous notes, trying to write as much down as they can. If the teacher asks a question, students shy away from answering them as they are embarrassed of speaking in front of their classmates or afraid of getting the answer wrong (Zhao, 2007; Mak, 2011). The significant phenomenon observed in many Asian countries is education in so called "private academies", in which numerous Asian students enrol after school, where there are teachers who teach the same material taught at school. These private academies also distribute additional homework for students. Numerous private academies are intensive and they open intensive courses during vacation and also make students stay at the academy until late evening. This phenomenon is unprecedented in South Korea (Bray, 2009).

The academic success of Confucian Heritage Culture students has been attributed, at least partially, to the efforts parents put into their children's learning and how much these parents value education. Chi-Chung Lam and co-workers have found that parents in Hong Kong respect and trust schoolteachers and they are very cooperative with teachers, but they are not ready to take a role of "decision makers" and would like to be "distant assistants" (Lam, Ho, Sui, Wong, 2002). This role of parents results in enhancing student achievement, reducing absenteeism and dropout rates, and improving homework habits (Ho, 2000). According to I.W. Pang, they tend to restrict their involvement to home because that makes both parents and teachers feel most comfortable (Pang, 1997).

\section{SOCRATIC EDUCATION PHILOSOPHY}

Socrates (469-399 B.C.E.), the Greek philosopher, remains one of the most influential figures in the history of Western philosophy. He was interested in ethics, conducts of life, and moral truth, or the higher ends in what one must do to be good (Abbs, 1993). Socrates talked in public - in the market place, outside 
the gymnasium, at parties, or wherever he happened to be. Moreover, he would talk philosophy with virtually anyone - fellow philosophers or sophists, public figures, playwrights, rich people or poor people, adults or children, and even slaves (Wang, 2013).

Socrates used the question-and-answer technique in his search for true knowledge. The process is described with details by Nel Noddings (2007). The simple question would be such as "What is truth?", or "What does it mean to be just?". When the other person answered, Socrates responded with another question that prompted him or her to think more deeply so as to offer a new answer. Such a strategy used by Socrates, which came to be known as the Socratic Method, has been regarded as perhaps one of the earliest teaching strategies ever described in education history, as writes Darcy Miller (2008). Socratic Method is a dialectic method of teaching that "involves dialogue and questioning, emphasizing the exchange of ideas and suppositions that then transforms knowledge itself" (Miller, 2008). Gary Alan Scott (2000) characterises Socratic method of education as the "integrative" model, in which new knowledge is thought to be substituted for, or integrated with old knowledge or belief in such a way that both the content and the form of one's knowledge might be said to be fundamentally reformulated, reconstituted, or reconfigured. The incompatibilities and inconsistencies in the various beliefs and opinions must be reconciled, and new ideas can be appropriated or assimilated to the old knowledge.

\section{COLLECTIVISM IN CONFUCIAN CULTURE VERSUS INDIVIDUALISM IN WESTERN CULTURE}

One of the most important dimensions of national culture identified by G. Hofstede (2001, described also by Wursten, Jacobs, 2017) is individualism vs. collectivism. In individualistic cultures, like almost all of the rich European/Western countries, and Poland, the USA, and Australia, people look after themselves and their immediate family only; in collectivist cultures, like Asia (South Korea, China, Japan, and Singapore) and Africa, people belong to "in-groups" who look after them in exchange for loyalty. In individualist cultures values are in persons, whereas in collectivist cultures identity is based on the social network to which one belongs. In individualist cultures there is more explicit, verbal communication. In collectivist cultures, communication is more implicit (Hall, 1976; Hofstede, 1980; Ting-Toomey, Chung, 1996; Kim, Lim, Dindia, Burrell, 2010). 
According to Triandis, McCusker, \& Hui (1990), individualists tend to think of individuals as the basic unit of analysis. Individualists are mostly concerned about having the freedom to do their own thing. In the individualistic cultures certain values are emphasized, such as freedom, equality, creativity, bravery, independence and competition from the in-group (Triandis et al., 1990). In contrast, collectivists tend to think of groups as the basic unit of analysis of society (Triandis et al., 1990). This tendency will become even stronger in collectivist cultures because the emphasis on in-group harmony requires in-group members to conform and to be homogeneous. In collectivistic cultures, behaviour is regulated largely by in-group norms, which are more important determinants of social behaviour. Furthermore, harmony is an important attribute. The in-group is supposed to be homogeneous in opinion, and no disagreements should be known to out-groups (Wang, 2013). With regard to values, collectivist cultures stress social recognition, loyalty, tradition, being humble, honouring parents and elders, obedience to authority and proper behaviour as key values (Triandis et al, 1990).

Learners from CHC context prefer working in groups and perform better in groups (Chan, Watkins, 1994; Park, 2002; Hofstede, Hofstede, 2005). Cooperative learning strategies have been strongly recommended for collectivist learners (Salili, 1996). Group learning is assumed to be culturally appropriate in CHC and many Asian collectivist nations. Group learning, from a Western perspective, means working within a social constructivist environment in which students, using their collective knowledge, may exceed the knowledge of their teacher and thereby bring the teacher's knowledge into question (Nguyen, Terlouw, Pilot, 2006).

The education in Asian countries focuses, similar as in Western countries, on "critical thinking skills", on "problem-solving", on "creativity", which are seen to be readily compatible with apparently rote styles of learning. Such shifts might be understood as reflecting the influence of "Western" approaches to learning, or as the results of economic developments in many Asian economies (Mason, 2014; Durkin, 2008).

Taylor (1990) points out that in addition to learning style differences between cultural groups, variations also exist in the rules for general discourse in oral (verbal) communication. Teachers and students will naturally follow the assumptions and rules from their respective cultures. Any analysis of interpersonal communication in the classroom is incomplete without considering non-verbal aspects of communication. Understanding of a communication derives from the 
interaction of the verbal and non-verbal activities with each other and with the context in which they occur (Hall, 1985). Minimum communicative competence includes the meaning of a smile, eye contact, conversational distance, and actual touching; in Asian cultures are important the following aspects: time, space, and context (Littrell, 2006). Teaching in most East Asian countries is traditionally dominated by a teacher-centred, book-centred method and an emphasis on rote memory (Liu, Littlewood, 1997). These traditional teaching approaches have resulted in a number of common learning styles. According to some Western academics, the CHC students are modest and diligent (Park, 2000), but at the same time, some of their typical learning characteristics are described negatively such as rote, silent and passive style of learning (Cf. Sit, 2013).

Jin Li (2012) grew up thoroughly Chinese even though she has lived in the USA for many years, thus in her book Cultural Foundations of Learning: East and West in such manner she summarized the Confucian learning tradition, which holds to the following: (a) learning is the most important thing in life; it is life's purpose; (b) learning enables one to become a better, not just smarter person; (c) learning is a life-long process; (d) the kind of knowledge that sets one person apart from another does not come to one automatically. One must seek it. Seeking knowledge requires resolve, diligence, enduring hardship, steadfastness, concentration, and humility. In contrast, students from Western cultures have a different approach to learning, which follows the key themes: a. human curiosity about the external world is the inspiration for knowledge; $b$. a relentless spirit of inquiry into the universe will lead to knowledge; c. mind is the highest human faculty that enables this inquiry; $d$. reason (not heart) is the process by which we know the world; e. the individual is the sole entity for inquiry, discovery and ultimate triumph.

\section{CONCLUSIONS}

Different cultural and social factors in Ancient Greece and China led to differences but also to similarities in Socratic and Confucian educational philosophy, which has been examined from the perspectives of the aim of education, the content of education, the teaching process, and the nature of education. The basics of Socrates' education were individualistic and rationalist traits, while Confucius' teaching was distinctively marked with collective and intuitive characteristics. Their philosophies of education impacted not only their disciples, but Western 
and Asian educational practice as a whole. Studying a particular teaching or learning style in these countries, the cultural contexts should always be taken into consideration. In traditional Confucian culture, a love of learning is a moral imperative and is achieved over time by the development of moral virtues, filial piety, modesty, effort, and perseverance. In contrast, Western students value independence and individual effort in order to achieve the "prize" in the shape of grades, income and status. But Asian students are influenced by Western culture via social media, the Internet, movies and cross-cultural exchanges. However, there are still Confucian characteristics that persist, because Confucian culture is deeply rooted in South-East Asian families.

\section{REFERENCES:}

Abbs, P. (1993). Socratic Education. A. McClelland (ed.). London: UHP.

Ark, A. (2013). Culture, Confucianism, and Communication: How Culture Affects International Students from China and Taiwan Who Come to the U.S. to Study Education. A Thesis in Middle State University in the Midwest.

Bray, M. (2009). Confronting the Shadow Education System: What Government Policies for What Private Tutoring? Paris: UNESCO International Institute for Educational Planning.

Chambliss, J.J. (ed.). (1996). Philosophy of Education: An Encyclopaedia. New York, London: Garland Publishing, Inc.

Chan, W.T (1963). A Sourcebook in Chinese Philosophy. Princeton: Princeton University Press.

Chan, G., Watkins, D. (1994). Classroom Environment and Approaches to Learning: An Investigation of the Actual and Preferred Perceptions of Hong Kong Secondary School Students. Instructional Science, 22(3), 233-246.

Chen, J. (1990). Confucius as a Teacher. Beijing: Foreign Languages Press.

Confucius: The Analects [AL] (Lun Yu) (1983) D.C. Lau, trans., Hong Kong: The Chinese University Press, 7:24, 15:38, 1:8.

De Bary, W.T. (1996). Confucian Education in Premodern East Asia. In: Tu Wei-ming (ed.), Confucian Traditions in East Asian Modernity. Cambridge, Mass.: Harvard University Press.

Durkin, K. (2008). The Adaptation of East Asian Masters Students to Western Norms of Critical Thinking and Argumentation in the UK. Intercultural Education, 19(1), 15-27. DOI: $10.1080 / 14675980701852228$.

Education Style: Asian vs Western (2017). Retrieved from: http://support.acadsoc.com/ education-style-asian-vs-western-6-178-702.html.

Gudykunst, W.B., Ting-Toomey, S., Nishida, T. (eds.). (1996). Communication in Personal Relationships Across Cultures. USA: Sage Publications. 
Gudykunst, W.B., Matsumoto, Y. (1996). Cross-cultural Variability of Communication in Personal Relationships. In: W.B. Gudykunst, S. Ting-Toomey, T. Nishida (eds.), Communication in Personal Relationships Across Cultures (p. 19-56). USA: Sage Publications.

Hall, E.T. (1976). Beyond Culture. Garden City, NY: Anchor Press/Doubleday.

Hall, E.T. (1985). Hidden Differences: Studies in International Communication. Hamburg: Grunder \& Jahr.

Ho, E.S. (2000). The Nature and Impact of Social Capital in Three Asian Educational Systems: Singapore, Korea, and Hong Kong. International Journal of Educational Policy, Research and Practice, 1(2), 171-189.

Hofstede, G.H. (1980). Motivation, Leadership, and Organization: Do American Theories Apply Abroad? Organizational Dynamics, 9(1), 42-63.

Hofstede, G.H. (2001). Culture’s Consequences. Comparing Values, Behaviors, Institutions and Organizations Across Nations. USA: Sage Publications.

Hofstede, G.H., Hofstede, J. (2005). Cultures and Organization-software of the Minds ( $2^{\text {nd }}$ ed.). New York: McGraw-Hill.

Hwang, K.K. (1999). Filial Piety and Loyalty: Two Types of Social Identification in Confucianism. Asian Journal of Social Psychology, 2(1), 163-183. DOI: 10.1111/1467-839X.00031.

Hwang, K.K. (2001). The Deep Structure of Confucianism: A Social Psychological Approach. Asian Philology, 11(3), 179-204. DOI: 10.1080/09552360120116928.

Irvine, J.J. (2010). Culturally Relevant Pedagogy. Education Digest: Essential Readings Condensed for Quick Review, 75(8), 57-61.

Juszczyk, S. (2013). Badania jakościowe w naukach społecznych. Szkice metodologiczne. [Qualitative Research in the Social Sciences. Methodological Sketches]. Katowice: University of Silesia Press.

Juszczyk, S., Kim, Y.D. (2017). Impact of Culture on Education in Poland and South Korea. A Comparative Analysis. The New Educational Review, 48(2), 132-143. DOI: 10.15804/tner.2017.48.2.10.

Kim, J., Lim, T.S., Dindia, K., Burrell, N. (2010). Reframing the Cultural Differences Between the East and the West. Communication Studies, 61(5), 543-566.

Kincheloe, J.L., McLaren, P. (2000). Rethinking Critical Theory and Qualitative Research. In: N.K. Denzin, Y.S. Lincoln (eds.), Handbook of Qualitative Research ( $2^{\text {nd }}$ ed.) (p. 279-313). USA: Sage Publications.

Ladson-Billings, G. (1995). Toward a Theory of Culturally Relevant Pedagogy. American Educational Research Journal, 32(3), 465-491.

Lam, Ch., Ho, Ch., Sui, E., Wong, N.Y. (2002). Parents' Beliefs and Practices in Education in Confucian Heritage Cultures: The Hong Kong Case. Journal of Southeast Asian Education, 3(1), 99-114.

Lee, W.O. (1996). The Cultural Context for Chinese Learners: Conceptions of Learning in the Confucian Tradition. In: D.A. Watkins, J.B. Biggs (eds.), The Chinese Learner: Cultural, Psychological and Contextual Influences (p. 25-41). Hong Kong: 
Comparative Education Research Centre and Victoria, Australia: The Australian Council for Educational Research.

Lee, J.K. (2001). Confucian Thought Affecting Leadership and Organizational Culture of Korean Higher Education. Radical Pedagogy, 3(3), 1-11. Retrieved from: http:// radicalpedagogy.icaap.org/content/issue3-3/5-lee.html.

Li, J. (2012). Cultural Foundations of Learning: East and West. New York: Cambridge University Press.

Littrell, R.F. (2006). Learning Styles of Students in and from Confucian Cultures. Retrieved from: https://www.researchgate.net/publication/228347305_Learning_styles_of_students_in_and_from_Confucian_cultures.

Liu, N.F., Littlewood, W. (1997). Why do Many Students Appear Reluctant to Participate in Classroom Learning Discourse? System, 25(3), 371-384.

Mak, B. (2011). An Exploration of Speaking-in-Class Anxiety with Chinese ESL Learners. System, 39(2), 202-214.

Mason, M. (2014). Culture and Educational Outcomes in "Confucian heritage" Societies in Asia. Retrieved from: http://ries.revues.org/3812. Colloques internationaux, Colloque: Léducation en Asie en 2014: Quels enjeux mondiaux?

Mason, M. (2014). Comparing Cultures. In: M. Bray, B. Adamson, M. Mason (eds.), Comparative Education Research: Approaches and Methods (p. 165-196). Hong Kong and Dordrecht: CERC and Springer.

Markus, H.J., Kitayama, S. (1991). Culture and the Self: Implications for Cognition, Emotion and Motivation. Psychological Review, 98(2), p. 224-253.

Miller, D. (2008). Learning Strategies. In: N.J. Salkind, K. Rasmussen (eds.), Encyclopedia of Educational Psychology, Vol. 2. London: Sage Publications.

Moore, A. (2000). Teaching and Learning: Pedagogy, Curriculum and Culture. New York: Routledge Palmer.

Morris, J. (2014). Asian Countries Dominate Global Education Ranking. Retrieved from: https://www.cnbc.com/2014/05/08/asian-countries-dominate-global-educationranking.html.

Muller, Ch. (transl.). (1990). The Analects of Confucius. Retrieved from: http://www. acmuller.net/con-dao/analects.html.

Nguyen, P.M., Terlouw, C., Pilot, A. (2006). Culturally Appropriate Pedagogy: The Case of Group Learning in a Confucian Heritage Culture Context. Intercultural Education, 17(1), 1-19.

Noddings, N. (2007). Philosophy of Education (2 $2^{\text {nd }}$ ed.). Colorado: Westview Press.

Pang, I.W. (1997). Functions of the Parent-Teacher Association (PTA): A Hong Kong Perspective. Educational Journal, 25(1), 81-106.

Park, C.C. (2000). Learning Style Preferences of Southeast Asian Students. Urban Education, 35(3), 245-268.

Park, C.C. (2002). Cross-cultural Differences in Learning Style of Secondary English Learners. Bilingual Research Journal, 26(2), 443-459. 
"Pearson Education" is a British-owned Education Publishing and Assessment Service to School and Corporations, as Well as Directly to Students. Retrieved from: http:// home.pearsonhighered.com.

Pusch, M.D. (ed.). (1979). Multicultural Education. NY: Intercultural Press, Inc.

Salili, F. (1996). Accepting Personal Responsibility for Learning. In: D. Watkins, J. Biggs (eds.), The Chinese Learner: Cultural, Psychological and Contextual Influences (p 86-105). Hong Kong: CERC and ACER, The Central Printing Press.

Scott, G.A. (2000). Plato's Socrates as Educator. NY: State University of New York Press.

Sit, H.H.W. (2013). Characteristics of Chinese Students' Learning Styles. Retrieved from: http://www.ipedr.com/vol62/008-ICLMC2013-M10004.pdf.

Starr, D. (2012). China and the Confucian Education Model. A Position Paper Commissioned and Published by Universitas 21, the Leading Global Network of Research Universities for the $21^{\text {st }}$ Century.

Taylor, O.L. (1990). Cross-Cultural Communication: An Essential Dimension of Effective Education, Revised Edition. Washington, D.C.: The Mid-Atlantic Equity Center.

Ting-Toomey, S., Chung, L. (1996). Cross-Cultural Interpersonal Communication: Theoretical Trends and Research Directions. In: W.B. Gudykunst, S. Ting-Toomey, T. Nishida (eds.), Communication in Personal Relationships Across Cultures (p. 237-261). USA: Sage Publications.

Triandis, H.C., McCusker, C., Hui, C.H. (1990). Multimethod Probes of Individualism and Collectivism. Journal of Personality and Social Psychology, 59(5), 1006-1020.

Tweed, R., Lehman, D. (2002). Learning Considered Within a Cultural Context: Confucian and Socratic Approaches. American Psychologist, 57(2), 89-99.

Wang, H. (2013). Cultural Interpretations of Socratic and Confucian Education Philosophy. (dissertation, 2013). Retrieved from: http://ir.library.louisville.edu/cgi/ viewcontent.cgi?article $=1604 \&$ context $=$ etd.

Watkins, D.A., Biggs, J.B. (eds.). (1996). The Chinese Learner: Cultural, Psychological and Contextual Influences. Hong Kong: CERC and ACER.

Wursten, H., Jacobs, C. (2017). The Impact of Culture on Education. Retrieved from: https://geert-hofstede.com/tl_files/images/site/social/Culture\%20and\%20education.pdf.

Yun, S.S. (1996). Confucian Thought and Korean Culture. In: J.W. Kim (ed.), Koreana: Korean Cultural Heritage, Vol. II. Thought and Religion. Seoul, Korea: Samsung Moonhwa Printing Co.

Zhao, Z. (2007). Schooling in China. In: G.A. Postiglione, J. Tan (eds.), Going to School in East Asia (p. 65-85). Westport, CT: Greenwood Press. 